\title{
Assay for high glucose-mediated islet cell sensitization to apoptosis induced by streptozotocin and cytokines
}

\author{
Jose M. Mellado-Gil ${ }^{1}$ and Manuel Aguilar-Diosdado ${ }^{1 *}$
}

\author{
${ }^{1}$ Endocrinology Service and Research Unit, Puerta del Mar Hospital, Cadiz, Spain. \\ *Corresponding Author: Manuel Aguilar-Diosdado, Servicio de Endocrinologia. Hospital Puerta del Mar. Avda Ana de Viya $n^{\circ} 2111009$ Cadiz, Spain. \\ Phone: +34 (9)56 002814; Fax: +34 (9)56 002315; Email: manuel.aguilar.sspa@juntadeandalucia.es
}

Submitted: August 3, 2005; Revised: October 10, 2005; Accepted: October 11, 2005.

Indexing terms: Apoptosis; Diabetes Mellitus; Streptozotocin; Cytokines.

\begin{abstract}
Pancreatic $\beta$-cell apoptosis is known to participate in the $\beta$-cell destruction process that occurs in diabetes. It has been described that high glucose level induces a hyperfunctional status which could provoke apoptosis. This phenomenon is known as glucotoxicity and has been proposed that it can play a role in type 1 diabetes mellitus pathogenesis. In this study we develop an experimental design to sensitize pancreatic islet cells by high glucose to streptozotocin (STZ) and proinflammatory cytokines [interleukin (IL)- $1 \beta$, tumor necrosis factor (TNF)- $\alpha$ and interferon (IFN)- $\gamma$ ]-induced apoptosis. This method is appropriate for subsequent quantification of apoptotic islet cells stained with Tdt-mediated dUTP Nick-End Labeling (TUNEL) and protein expression assays by Western Blotting (WB).
\end{abstract}

\section{INTRODUCTION}

Type 1 diabetes mellitus results from autoimmune T-cellmediated destruction of insulin-producing pancreatic islet $\beta$-cells (1). Although the mechanism of how this destruction takes place is not completely understood, $\beta$ cell apoptosis is known to participate in this process (24). IL-1 $\beta$ alone or in combination with other proinflammatory cytokines inhibits the glucose-induced insulin secretion and plays an important role in $\beta$-cell death by inducing toxic nitric oxide $(\mathrm{NO})$ production and extracellular signal-regulated kinase (ERK) activation in the islet (5-8). Streptozotocin (STZ) has been used widely to produce animal models of diabetes. The effects of STZ on $\beta$-cells are similar to those of IL-1 $\beta$ and also seem to be mediated by NO (9) through alkylation, DNA damage and poly-ADP ribose polymerase (PARP) activation (10). Furthermore, there are mounting evidences that have recently shown an important role of $\beta$-cell death in type 2 diabetes mellitus (11).

The pancreatic microenvironment can play an important function in $\beta$-cell death, making these cells more suscept- ible or resistant to damage. High glucose concentration impairs islet function by disturbing glucose metabolism in $\beta$-cells mitochondria and induces apoptosis (12-14). In addition, it has been reported that high glucose concentration could enhance 8 -cell vulnerability to toxic effects by increasing the expression of potential autoantigens on the cell membrane surface (15).

Based on the above-cited evidence, this study presents a method for the "in vitro" sensitization of islet cell, by using high subtoxic-to-toxic glucose concentrations, to STZ and cytokine-induced apoptosis. This method keeps the islets undamaged, so that, after trypsin dissociation, the cells can be stained by TUNEL. Also, the islets obtained were used to determine expression of apoptosis-related proteins like the cell death receptor Fas (CD95), Bcl-xL and Bcl-2, by WB. Fas seems to be implicated in $\beta$-cell apoptosis via an intracellular death domain (16) and proinflammatory cytokines can induce up-regulation of Fas expression on $\beta$-cells, making them susceptible to apoptosis in the presence of agonistic antiFas antibodies or interaction with Fas-ligand (FasL, CD95L)-expressing T-cells (17-19). The role of Fas in $\beta$ - 
cell apoptosis is still under debate and has been challenged by several studies $(20,21)$. In addition, upregulation of several anti-apoptotic members of the Bcl-2 family of proteins, such as Bcl-2 and Bcl-xL has been closely associated with increased resistance to apoptosis and potentially to diabetes susceptibility (22-24). The expression of these genes may possibly be modified by the functional status of the $\beta$-cell, especially when associated with a high glucose concentration.

\section{MATERIALS AND METHODS}

\section{Isolation and culture of rat islets}

All animal procedures were performed with the approval of the Animal Ethical Use and Care Committee at the Cadiz University School of Medicine, Cadiz, Spain. Pancreatic islets were isolated from 200-250 g weight adult male Wistar rats, as described previously (25). In brief, animals were sacrificed and the pancreas was filled with a cold solution of colagenase $\mathrm{P}(1 \mathrm{mg} / \mathrm{ml})$ in HBSS through a catheter introduced into the part of the choledoco running from the liver to the pancreas. Then the filled pancreas was extracted and digested at $37^{\circ} \mathrm{C}$ for $20 \mathrm{~min}$. while being agitated. Islets were isolated from the digested pancreas by density gradients, collected and cultured in Petri plates (100 islets on a $60 \mathrm{~cm}$ plate with 5 $\mathrm{ml}$ of culture medium) with RPMI (Sigma, St Louis, MO) supplemented with $2 \mathrm{mM}$ L-glutamine (Gibco,Invitrogen Limited, Paisley, UK), 10\% fetal bovine serum (Gibco, Invitrogen Limited, Paisley, UK), $100 \mathrm{U} / \mathrm{ml}$ penicillin and $100 \mu \mathrm{g} / \mathrm{ml}$ streptomycin (Pen-Strep; Bio-Whittaker Europe, Verviers, Belgium) and containing the established glucose concentration for each experiment.

\section{Sensitization protocol}

First, the glucose concentration adequate for islet cell sensitization was determined by a dose-response experiment. This was performed using 2, 5.5, 11.1, 24.4 and $33.3 \mathrm{mM}$ glucose and measuring different apoptosis rates by TUNEL-staining. The highest concentration which did not induce apoptosis "per se" was $24.4 \mathrm{mM}$ glucose; therefore this concentration was compared with $5.5 \mathrm{mM}$ which was considered as the optimal concentration.

\section{Sensitization to STZ-induced damage}

Islets were cultured for a sensitization period (48h) with RPMI-completed medium supplemented with 5.5 or 24.4 $\mathrm{mM}$ glucose. After this period, the medium was replenished with fresh culture medium supplemented with 5.5. $\mathrm{mM}$ glucose for the all islets, maintaining the batches of islets separated according to the previous glucose concentration (during the sensitization period). Then STZ (Sigma, St Louis, MO) was added to the islet cultures for an incubation period of $24 \mathrm{~h}$.

\section{Sensitization to cytokine-induced damage}

Islets were cultured for an overnight period ( $\approx 14-16 \mathrm{~h})$ with RPMI-completed medium supplemented with 5.5 or $24.4 \mathrm{mM}$ glucose. The culture medium was replenished with fresh medium maintaining the glucose concentration either with IL-1 $\beta$ (PeproTech EC Ltd, London, UK) alone or with IL-1 $\beta+$ TNF- $\alpha$ (PeproTech EC Ltd., London, UK) + IFN- $\gamma$ (PeproTech EC Ltd, London, UK). These alternative mixtures of medium were added to the islets cultured for a incubation period of $24 \mathrm{~h}$. The specific cytokine ( $50 \mathrm{U} / \mathrm{ml} \mathrm{IL}-1 \beta ; 1,000 \mathrm{U} / \mathrm{ml}$ IFN- $\gamma ; 1,000 \quad \mathrm{U} / \mathrm{ml}$ TNF- $\alpha)$ and STZ $(1.5 \mathrm{mM})$ concentrations used in these experiments were selected from previous studies (26-28).

\section{Detection of apoptotic cells}

Apoptotic cells were detected using the TUNEL technique. Following treatment with cytokines or STZ, islets were incubated for $15 \mathrm{~min}$ with Trypsin-EDTA, $0.25 \%$ trypsin, $1 \mathrm{mM}$ EDTA $\bullet 4 \mathrm{Na}$ in Hanks' balanced salt solution without $\mathrm{Ca}^{2+}$ and $\mathrm{Mg}^{2+}(\mathrm{Gibco}$, Invitrogen Limited, Paisley, UK) at $37^{\circ} \mathrm{C}$, and the islet cells were gently dispersed. After washing with PBS, the cells were cytospun on Poly-L-lysine-coated slides, fixed in $4 \%$ methanol-free formaldehyde solution in PBS for $25 \mathrm{~min}$ at $4^{\circ} \mathrm{C}$, and stored in $70 \%$ ethanol at $-20^{\circ} \mathrm{C}$ until detection of apoptotic cells by TUNEL assay. The TUNEL assay was performed according to the manufacturer's instructions (Apoptosis Detection System, Fluorescein; Promega Corporation, Madison, WI) (29). The fluorescein-12dUTP-labeled DNA was directly visualized by fluorescence microscopy with excitation at $520 \pm 20 \mathrm{~nm}$, to allow counting of the proportion of apoptotic cells (nuclei with green fluorescence). Cell 
nuclei were stained with propidium iodide (red fluorescence). Apoptotic and total nuclei were counted in a blinded fashion in two slides per condition and per experiment.

\section{Western blot}

Equal numbers of islets treated according to the various experimental conditions described above were lysed in $60 \mathrm{mM}$ Tris- $\mathrm{HCl}$ pH-6-8, 2\% SDS, 10\% glycerol, $0.0012 \%$ bromophenol blue, and $5 \% \beta$-mercaptoethanol. Islet lysates were boiled for 5 minutes and then loaded on a $10-12 \%$ SDS-polyacrylamide gel. An amount of lymphocytes of chronic lymphoid leukemia (CLL) equivalent to number of islet cells per condition were used as positive control for Bcl-2. Proteins were transferred to PDVF membrane and the blot was then incubated in blocking buffer ( $5 \%$ non-fat milk in $10 \mathrm{mM}$ Tris- $\mathrm{HCl}, 1.15 \mathrm{M} \mathrm{NaCl}$ and $0.1 \%$ Tween-20) for $1 \mathrm{~h}$ at room temperature. Next the blots were incubated with polyclonal antibodies against Fas (1:500 dilution; Santa Cruz Biotechnology Inc, Santa Cruz, CA), Bcl-xL (1:500 dilution; Santa Cruz Biotechnology Inc, Santa Cruz, CA), Bcl-2 (1:100 dilution; Abcam Ltd, Cambridge, UK), or actin (1/5000 dilution; Abcam Ltd, Cambridge, UK) for 2 $\mathrm{h}$ at room temperature, followed by incubation with the appropriate alkaline phosphatase-linked secondary antibody at room temperature for $1 \mathrm{~h}$. Protein band detection was performed by adding 5-bromo-4-chloro-3indolyl phosphate/ nitroblue tetrazolium (BCIP/NBT; Bio-Rad Laboratories, Hercules, CA) to the membranes. Data from the densitometry of the bands was captured using BioCaptMW-[BioCaptMW-1] software. In each experiment, band densities were normalized against actin, and the results are expressed as protein level to control islets $(C=1)$.

\section{Statistical analysis}

Results are presented as mean \pm S.E.M. in at least three independent and separate experiments. Statistical analysis was performed using the Mann-Whitney test and a P value less than 0.05 was considered statistically significant.

\section{RESULTS AND DISCUSSION}

\section{Effect of glucose concentration on islet cell apoptosis}

It has recently been reported that chronic exposure to high glucose (for more than two days) leads to increased rat islet cell apoptosis (30). In the current study we first analyzed rat islet cell apoptosis in a glucose doseresponse curve for $48 \mathrm{~h}$; an increased percentage of islet cell apoptosis was observed with low $(2 \mathrm{mM})$ and very high $(33.3 \mathrm{mM})$ glucose concentrations in the medium, but not with 5.5, 11.1 or $24.4 \mathrm{mM}$ glucose (Fig. 1).

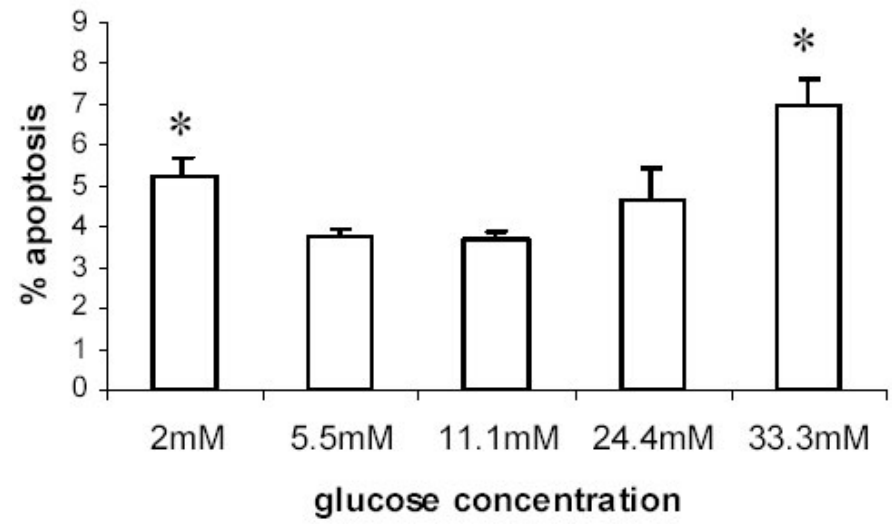

Fig. 1: Glucose dose-response curve. The islets were cultured with 2, 5.5, 11.1, 24.4 and $33.3 \mathrm{mM}$ glucose for $48 \mathrm{~h}$. Apoptotic cells were assessed by the TUNEL method under fluorescence microscopy. Data are expressed as the percentage of apoptotic cells. ${ }^{\star} P<0.05$ vs control $5.5 \mathrm{mM}$ and $P<$ 0.05 vs control $11.1 \mathrm{mM}$.

\section{Effect of sensitization period on STZ-induced islet cell apoptosis}

Examination of TUNEL-stained cell preparations of islets maintained in 5.5 or $24.4 \mathrm{mM}$ glucose for $48 \mathrm{~h}$ and incubated with STZ for $24 \mathrm{~h}$ was performed. We chose a dose of STZ that did not significantly increase rates of apoptosis in rat islet cells preincubated in $5.5 \mathrm{mM}$ glucose for $48 \mathrm{~h}$. Interestingly, apoptosis increased significantly (by $50 \%$ ) when rat islets were incubated in $24.4 \mathrm{mM}$ glucose for $48 \mathrm{~h}$ with a low dose of STZ $(1.5 \mathrm{mM})$ for an additional $24 \mathrm{~h}$ period (Fig. 2). The rationale for STZ incubation with glucose $5.5 \mathrm{mM}$ was to avoid competition between high glucose concentration and STZ for the glucose transporter GLUT-2 $(31,32)$. 


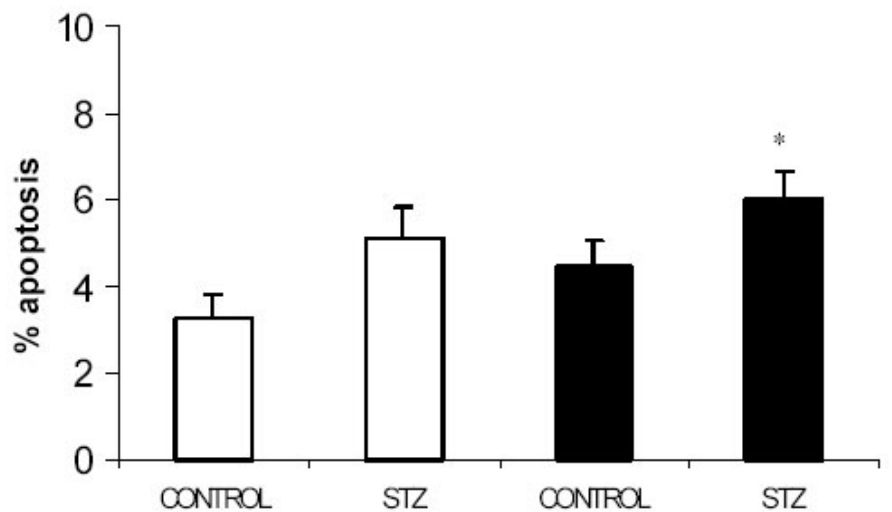

Fig. 2: Influence of different glucose concentrations (5.5 or $24.4 \mathrm{mM}$ ) on islet cell apoptosis induced by STZ $(1.5 \mathrm{mM})$. The islets were cultured either with $\mathbf{5 . 5}$ or $\mathbf{2 4 . 4} \mathrm{mM}$ glucose and exposed to STZ. Apoptotic cells were assessed by the TUNEL method under fluorescence microscopy. Data are expressed as the percentage of apoptotic cells. Open bars, islets cultured with $5.5 \mathrm{mM}$ glucose; filled bars, islets cultured with $24.4 \mathrm{mM}$ glucose. ${ }^{*} P<0.05$ vs control $24.4 \mathrm{mM}$ glucose.

\section{Effect of sensitization period on cytokine-induced islet cell apoptosis}

We next analyzed whether high glucose also increases the sensitivity of rat islet cells to apoptosis induced by IL-1 $\beta+$ TNF- $\alpha+$ IFN- $\gamma$ during the previous $24 \mathrm{~h}$. As shown in Fig. 3, a dose of cytokines that did not induce a significant increase in islet cell apoptosis at $5.5 \mathrm{mM}$ glucose, was capable of inducing a significant two-fold increase in the apoptosis rates of islet cells maintained at $24.4 \mathrm{mM}$ glucose. Rates of apoptosis in islet cells incubated in high glucose rose from $6.09 \pm 0.78 \%$ to 13.07 $\pm 1.78 \%(\mathrm{p}<0.01)$, when cytokines were added. This result indicates that the sensitization period at $24.4 \mathrm{mM}$ glucose makes cells more susceptible to the apoptosis effects induced by cytokines. The percentage of apoptotic cell in islets incubated with high glucose concentration $(24.4 \mathrm{mM})$ and cytokines were significantly higher than in islets with cytokines but incubated in $5.5 \mathrm{mM}$ glucose $(13.07 \pm 1.78 \%$ vs. $8.04 \pm 1.56 \%$ ( $p<0.05)$. Interestingly, this effect was only observed when the three cytokines were used in combination, since IL-1ß alone did not induce a significant increase in apoptosis at any glucose concentration tested. Collectively, these results suggest that although incubation for $48 \mathrm{~h}$ with high glucose does not induce an increase in rat islet cell apoptosis, it potentiates the pro-apoptotic effects of cytokines and STZ.

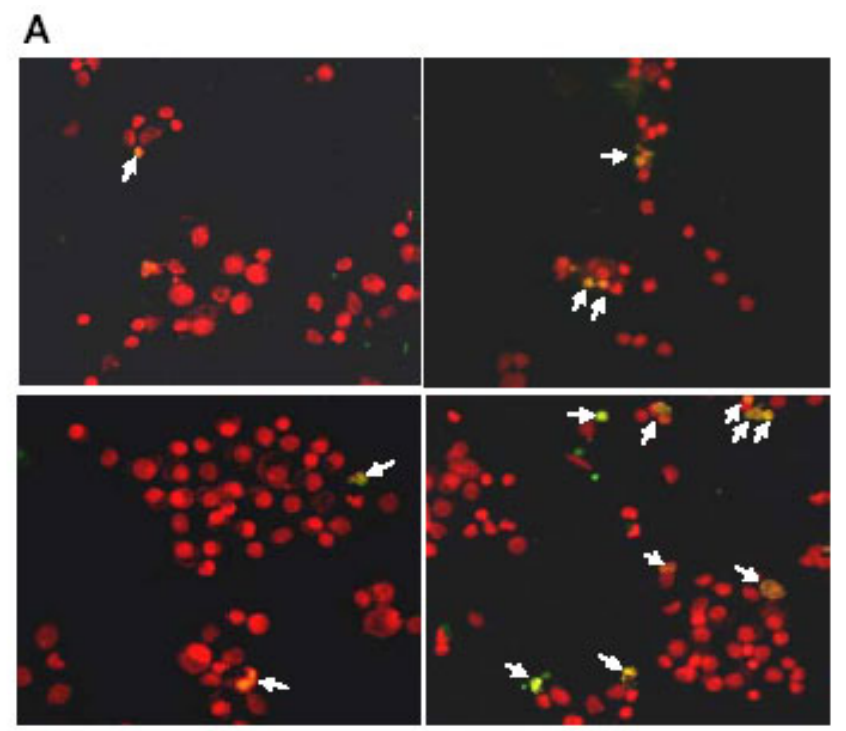

B

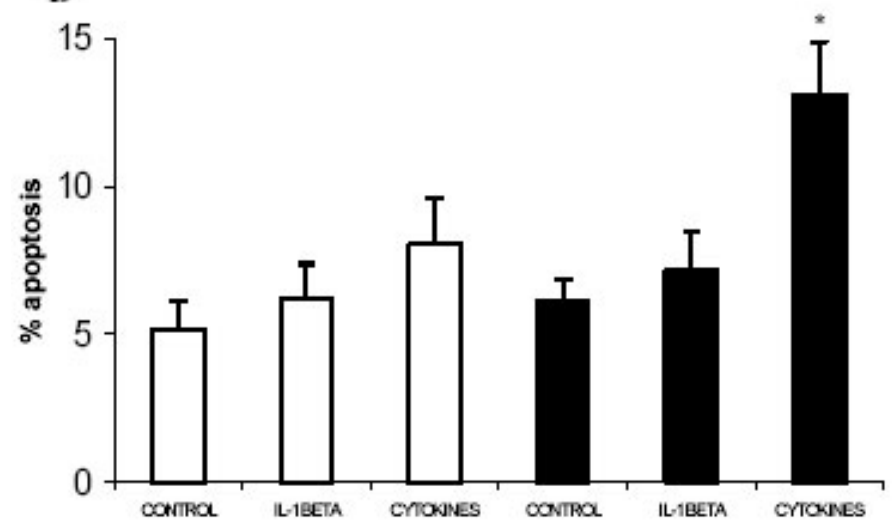

Fig. 3: Influence of different glucose concentrations (5.5 or $24.4 \mathrm{mM}$ ) on islet cell apoptosis induced by IL-1 $\beta$ and combined cytokines (IL-1 $\beta+$ IFN-y + TNF- $\alpha$ ). A. Representative microscopy images of apoptotic cells stained with TUNEL (green) and Propidium lodide (red). $5.5 \mathrm{mM}$ glucose control (upper left); $5.5 \mathrm{mM}$ glucose with cytokines (upper right); $24.4 \mathrm{mM}$ glucose control (bottom left) and $24.4 \mathrm{mM}$ glucose exposed to cytokines (bottom right). Arrows indicate apoptotic cells (co-location of red fluorescence of all cells plus green fluorescence of apoptotic cells). B. Percentage of apoptotic cells cultured with $\mathbf{5 . 5}$ or $\mathbf{2 4 . 4} \mathrm{mM}$ glucose and exposed to IL-1 $\beta$ and combined cytokines. Open bars, islets cultured with $5.5 \mathrm{mM}$ glucose; filled bars, islets cultured with $24.4 \mathrm{mM}$ glucose. ${ }^{*} P<0.01$ vs control $24.4 \mathrm{mM}$ glucose and $P<0.05$ vs. cytokines with $5.5 \mathrm{mM}$ glucose.

\section{Effect of sensitization period with high glucose on the expression of apoptosis-related proteins}

Fas is a death receptor involved in apoptosis in various cell types including islet cells (16-19). To determine whether glucose concentration has any impact in the expression of Fas in rat islet cells treated either with cytokines or STZ, we performed WB analysis of islet extracts incubated with the cell-death inducers in normal $(5.5 \mathrm{mM})$ and high $(24.4 \mathrm{mM})$ glucose concentrations. As it is shown in Figs. 4 and 5, incubation in high glucose for $48 \mathrm{~h}$ induced a significant increase $(\mathrm{p}<0.05)$ in the 
expression of Fas which was not modified when an incubation period with cytokines (Fig. 4) or STZ (Fig. 5) was performed. These results indicate that the sensitization period induces an increase in the expression of Fas in rat islet cells that is not associated with a rise in apoptosis. Moreover, high glucose potentiation of the apoptotic effects of cytokines and STZ does not correlate with an increase in Fas expression.

\section{A}

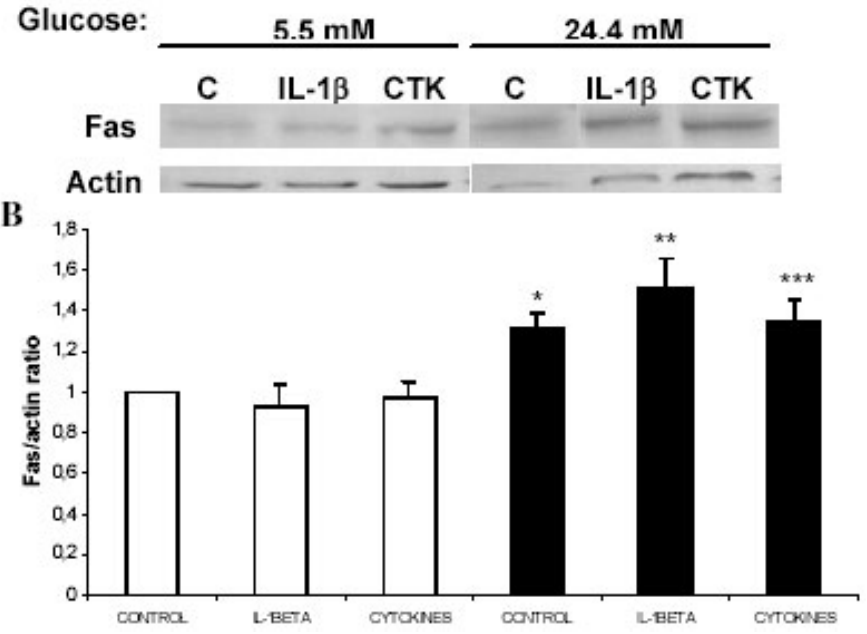

Fig. 4: Fas (CD95) expression in rat islets after exposure to IL-1 $\beta$ and combined cytokines (IL-1 $\beta$, TNF-y, IFN- $\alpha$ ). (A) Immunoblotting of Fas. Islets were cultured overnight with 5.5 or $24.4 \mathrm{mM}$ glucose and exposed to IL$1 \beta$ alone or combined with TNF- $\alpha$ plus IFN- $\gamma$, for $24 \mathrm{~h}$. Antibodies against Fas and actin were blotted in the same filter after stripping. One of at least three experiments is shown. Each experiment gave similar results. C, control; IL-1 $\beta$, interleukin-1 $\beta$; CTK, cytokines (IL-1 $\beta+$ TNF- $\alpha+$ IFN- $\gamma)$. (B) Densitometric quantitation of Fas-to-actin ratio showed a significant difference between $5 \mathrm{mM}$ and $24.4 \mathrm{mM}$ in the three groups (control, IL-1 and CTK). Y-axis represents arbitrary units. Open bars, islets cultured with $5.5 \mathrm{mM}$ glucose; filled bars, islets cultured with $24.4 \mathrm{mM}$ glucose. ${ }^{*} P<$ 0.05 vs control, $5.5 \mathrm{mM}$ glucose; $* * P<0.05$ vs. interleukin- $1 \beta, 5.5 \mathrm{mM}$ glucose; $* * * P<0.05$ vs. cytokines, $5.5 \mathrm{mM}$ glucose.

The anti-apoptotic proteins Bcl-xL and Bcl-2 expression were also studied after preculture with high glucose and treatment with the cytotoxic agents. As shown in Figures 6 and 7, we did not find any significant difference in the expression of either Bcl-xL or Bcl-2 in islets cultured at high or normal glucose concentration and treatment with cytokines (Fig. 6) or STZ (Fig. 7). However, while Bcl-xL was clearly detected, Bcl-2 was scarcely visible in all the conditions studied. As it has been described previously, basal expression of bcl-2 protein in pancreas islets seems to be very low and difficult to detect by WB $(33,34)$.

A

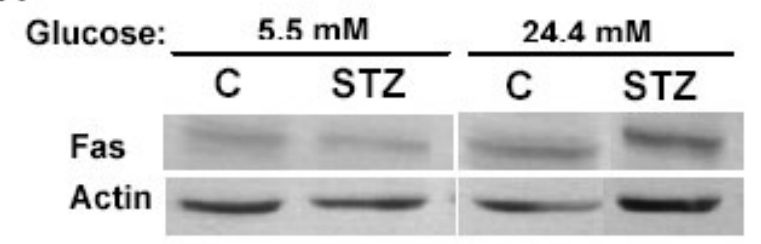

B

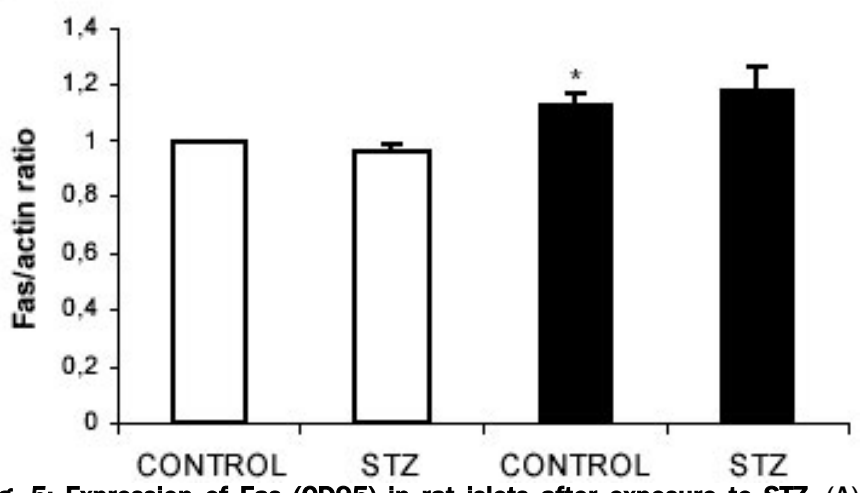

Fig. 5: Expression of Fas (CD95) in rat islets after exposure to STZ. (A) Immunoblotting of Fas. Islets were cultured for $48 \mathrm{~h}$ with 5.5 or $24.4 \mathrm{mM}$ glucose and exposed to STZ for $24 \mathrm{~h}$. Antibodies against Fas and actin were blotted in PVDF after stripping. One of at least three experiments is shown. Each experiment gave similar results. (B) Densitometric quantitation of Fas-to-actin ratio showed a significant difference between $5 \mathrm{mM}$ and $24.4 \mathrm{mM}$. Y-axis represents arbitrary units. Open bars, islets cultured with $5.5 \mathrm{mM}$ glucose; filled bars, islets cultured with $24.4 \mathrm{mM}$ glucose. ${ }^{*} P<0.05$ vs control, $5.5 \mathrm{mM}$ glucose.

However, the expression of other apoptosis-related genes could be analyzed after following the islet culture procedure shown in this work. Further studies will be required to clarify the molecular mechanisms responsible for the high-glucose enhancement of islet cell apoptosis induced by cytokines and STZ.

Glucose:
$5.5 \mathrm{mM}$

C IL-1 $\beta$ CTK CLL

$24.4 \mathrm{mM}$

\section{IL-1 $\beta$ CTK}

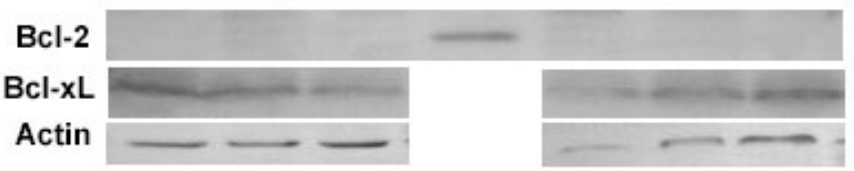

Fig. 6: Expression of Bcl-2 and Bcl-xL in rat islets after exposure to IL-1 $\beta$ and combined cytokines (IL-1 $\beta+$ TNF- $y+$ IFN- $\alpha$ ). Islets were cultured overnight with 5.5 or $24.4 \mathrm{mM}$ glucose and exposed to IL-1 $\beta$ alone or combined cytokines for $24 \mathrm{~h}$. Immunoblottings were performed using antibodies against Bcl-2 and Bcl-xL. Actin levels were determined as loading control. Densitometric quantitation of both Bcl-2 and Bcl-xL-toactin ratio did not generate significant differences (data not shown). One of at least three experiments is shown. Each experiment gave similar results. An amount of lymphocytes of chronic lymphoid leukemia (CLL) equivalent to number of islet cells per condition were used as positive

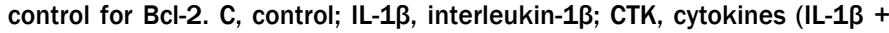
TNF- $\alpha+$ IFN-y). 


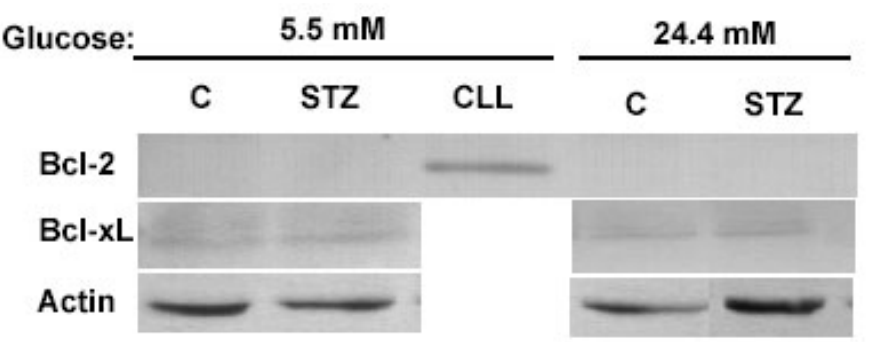

Fig. 7: Expression of $\mathrm{Bcl}-2$ and $\mathrm{Bcl}-\mathrm{xL}$ in rat islets after exposure to STZ. (A) Immunoblotting of Bcl-2, Bcl-xL and Fas. Islets were cultured for $48 \mathrm{~h}$ with $\mathbf{5 . 5}$ or $\mathbf{2 4 . 4} \mathrm{mM}$ glucose and exposed to STZ for $24 \mathrm{~h}$. The antibodies were blotted in different PVDF filters and antiactin after stripping was used for loading control. Densitometric quantitation of both $\mathrm{Bcl}-2$ and BclxL-to-actin ratio did not generate significant differences (data not shown). One of at least three experiments is shown. Each experiment gave similar results. An amount of lymphocytes of chronic lymphoid leukemia (CLL) equivalent to number of islet cells per condition were used as positive control for Bcl-2.

\section{Conclusion}

It is not well known whether high glucose concentration has any role in the apoptosis induced by STZ and cytokines in islet cells. We have designed an experimental method to assess the influence of glucose concentration on the effects of toxic agents classically involved in $\beta$-cell death and to analyze whether rat islet cell apoptosis induced by recognized islet cell toxic agents such as proinflammatory cytokines (IL- $1 \beta$, TNF- $\alpha$, IFN- $\gamma$ ) or STZ may be modulated by a pretreatment with high glucose concentration. In the study described here, we demonstrate that the presence of high glucose concentration in a preculture period enhances proinflammatory cytokine- and STZ-mediated apoptosis of rat pancreatic islet cells in vitro. Our results suggest that mechanisms involved in cytokine-induced apoptosis could be more amplified by the high glucose-induced hyperfunctional status of islet cells than the mechanisms implicated in STZ-mediated apoptosis. This effect could also be partially explained by recently reported glucoseinduced IL-1 $\beta$ production by $\beta$-cells (35). Some of the differences between our study and others could be due to species, time course, glucose concentration in the culture media and experimental models used. Thus, although murine dispersed islet cells survive best at 11 $\mathrm{mM}$ glucose and apoptosis increases when glucose is increased or decreased (29), we show a similar U-shape curve but no differences between 5.5, 11 and $24.4 \mathrm{mM}$ in whole rat islets. It is interesting to note that neither high glucose concentration nor the toxic agents used in this study caused marked apoptosis when used separately, and the higher levels of apoptosis were found when high glucose and cytokines, or STZ, existed simultaneously.
Our experimental design appears to be a feasible method for evaluating the influence of glucose on several stimuli causing $\beta$-cell damage and it seems to be adequate for determining synergistic and/or sensitization relationships between the effects of both high glucose concentration and potentially $\beta$-cells toxic agents (36).

\section{ACKNOWLEDGMENTS}

This work was supported by Grants from the Ministry of Health of Spain (FIS 99/1321), the Regional Government of Andalusia (SAS 177/99) and the Instituto de Salud Carlos III, RGMD (G03/212). There has not been any conflict of interest that would have prejudiced the impartiality of the research.

We thank Carmen Segundo for her aid and critical reading of the manuscript.

\section{REFERENCES}

1. Castaño L, Eisenbarth GS. Type 1 diabetes: a chronic autoimmune disease of human, mouse, and rat. Annu Rev Immunol 1990; 8:647-679.

2. O'Brien BA, Harmon BV, Cameron DP, Allan DJ. Apoptosis is the mode of [beta]-cell death responsible for the development of IDDM in the nonobese diabetic (NOD) mouse. Diabetes 1997; 46:750-757.

3. Kurrer MO, Pakala SV, Hanson HL, Katz JD. Beta cell apoptosis in $\mathrm{T}$ cell-mediated autoimmune diabetes. Proc Natl Acad Sci USA 1997; 94:213-218.

4. Augstein P, Elefanty AG, Allison J, Harrison LC. Apoptosis and beta-cell destruction in pancreatic islets of NOD mice with spontaneous and cyclophosphamide-accelerated diabetes. Diabetologia 1998; 41:1381-1388.

5. Kaneto H, Fujii J, Seo HG. Apoptotic cell death triggered by nitric oxide in pancreatic beta-cells. Diabetes 1995; 44:733-738.

6. Dunger A, Augstein P, Schmidt S, Fisher U. Identification of interleukin 1-induced apoptosis in rat islets using in situ specific labelling of fragmented DNA. J Autoimmun 1996; 9:309-313.

7. Dunger A, Schroder D, Augstein P, Witstruck T, Wachlin G, Vogt L, Ziegler B, Schmidt S. Impact of metabolic activity of beta cells on cytokine-induced 
damage and recovery of rat pancreatic islets. Acta Diabetol 1995; 32: 217-224.

8. Pavlovic D, Andersen NA, Mandrup-Poulsen T, Eizirik DL. Activation of extracellular signalregulated kinase (ERK) 1-2 contributes to cytokineinduced apoptosis in purified rat pancreatic b-cells. Eur Cyt Network 2000; 11:267-274.

9. Turk J, Corbett JA, Romanadham S, Bohrer A, McDaniel ML. Biochemical evidence for nitric oxide formation from streptozotocin in isolated pancreatic islets. Biochem Biophys Res Commun 1993; 197:14581464.

10. Masutani M, Suzuki H, Kamada N, Watanabe M, Ueda O, Nozaki T, Jishage K, Watanabe T, Sugimoto T, Nakagama H, Ochiya T, Sugimura T. Poly(ADPribose) polymerase gene disruption conferred mice resistant to streptozotocin-induced diabetes. Proc Natl Acad Sci USA 1999; 96:2301-2304.

11. Rhodes CJ. Type 2 diabetes - a matter of $\beta$-cell life and death? Science 2005; 307:380-384.

12. Sandler S, Bendtzen K, Eizirik DL, Strandell E, Welsh $\mathrm{M}$, Welsh N. Metabolism and beta-cell function of rat pancreatic islets exposed to human interleukin-1beta in the presence of high glucose concentration. Immunology Letters 1990; 26:245-252.

13. Laybutt R, Hasenkamp W, Groff A, Grey S, Jonas JC, Kaneto H, Sharma A, Bonner-Weir S, Weir G. Betacell adaptation to hyperglycemia. Diabetes 2001; 50:S180-S181.

14. Maedler K, Spinas GA, Lehmann R, Sergeev P, Weber M, Fontana A, Kaiser N, Donath MY. Glucose induces beta-cell apoptosis via upregulation of the Fas receptor in human islets. Diabetes 2001; 50:16831690.

15. Aguilar-Diosdado M, Parkinson D, Corbett JA, Kwon G, Marshall CA, Gingerich RL, Santiago JV, McDaniel ML. Potential autoantigens in insulin dependent diabetes mellitus: Expression of carboxypepetidase $\mathrm{H}$ and insulin but not glutamate decarboxylase on the $\beta$ cell surface. Diabetes 1994; 43:418-425.

16. Krammer PH. CD95's deadly mission in the immune system (Review). Nature 2000; 407:789-795.

17. Yamada K, Takane-Gyotoku N, Yuan X, Ichikawa F, Inada C, Nonaka K. Mouse islet cell lysis mediated by interleukin-1-induced Fas. Diabetologia 1996; 39:1306-1312.

18. Stassi G, Todaro M, Richiusa P, Giordano M, Mattina A, Sbriglia MS, Lo MA, Buscemi G, Galluzzo A, Giordano C. Expression of apoptosis-inducing CD95 (Fas/Apo-1) on human beta-cells sorted by flowcytometry and cultured in vitro. Transplant Proc 1995; 27:3271-3275.

19. Loweth AC, Williams GT, James RF, Scarpello JH, Morgan NG. Human islets of Langerhans express Fas ligand and undergo apoptosis in response to interleukin-1beta and Fas ligation. Diabetes 1998; 47:727-732.

20. Allison J, Strasser A. Mechanisms of beta cell death in diabetes: a minor role for CD95. Proc Natl Acad Sci USA 1998; 95:13818-13822.

21. Thomas HE, Darwiche R, Corbett JA, Kay TW. Evidence that beta cell death in the non-obese diabetic mouse is Fas independent. J Immunol 1999; 163:1562-1569.

22. Hanke J. Apoptosis and occurrence of Bcl-2, Bak, Bax. Fas and FasL in the developing and adult rat endocrine pancreas. Anat Embryol (Berl) 2000; 202:303-312.

23. Garchon HJ, Luan JJ, Eloy L, Bédossa P, Bach JF. Genetic analysis of immune dysfunction in nonobese diabetic (NOD) mice: mapping of a susceptibility locus close to the Bcl-2 gene correlates with increased resistance of NOD T cells to apoptosis induction. Eur J Immunol 1994; 24:380-384.

24. Lamhamedi-Cherradi SE, Luan JJ, Eloy L, Fluteau G, Bach JF, Garchon HJ. Resistance of T-cells to apoptosis in autoimmune diabetic (NOD) mice is increased early in life and is associated with dysregulation of Bcl-x. Diabetologia 1998; 41:178-184.

25. McDaniel ML, Colca JR, Kotagal N, Lacy PE. A subcellular fractionation approach for studying insulin release mechanisms and calcium metabolism in islets of Langerhans. Methods Enzymol 1983; 98:182-200.

26. Delaney CA, Pavlovic D, Hoorens A, Pipeleers DG, Eizirik DL. Cytokines induce deoxyribonucleic acid strand breaks and apoptosis in human pancreatic islet cells. Endocrinology 1997; 138:2610-2614.

27. Eizirik DL, Sandler S, Welsh N, Cetkovic-Cvrlje M, Nieman A, Geller DA, Pipeleers DG, Bendtzen K, 
Hellerström C. Cytokines suppress human islet function irrespective of their effects on nitric oxide generation. J Clin Invest 1994; 93:1968-1974.

28. Hoorens A, Pipeleers D. Nicotinamide protects human beta cells against chemically-induced necrosis, but not against cytokine-induced apoptosis. Diabetologia 1999; 42:55-59.

29. Efanova IB, Zaitsev SV, Zhivotovsky B, Kohler M, Efendic S, Orrenius S, Berggren PO. Glucose and tolbutamide induce apoptosis in pancreatic betacells: a process dependent on intracellular $\mathrm{Ca} 2+$ concentration. J Biol Chem 1998; 273:33501-33507.

30. Piro S, Anello M, Di Pietro C, Lizzio MN, Patane G, Rabuazzo AM, Vigneri R, Purrello M, Purrello F. Chronic exposure to free fatty acids or high glucose induces apoptosis in rat pancreatic islets: possible role of oxidative stress. Metabolism 2002; 51:13401347.

31. Schnedl WJ, Ferber S, Johnson JH, Newgard CB. STZ transport and cytotoxicity. Specific enhancement in GLUT2-expressing cells. Diabetes 1994; 43:1326-1333.

32. Szkudelski T. The mechanism of alloxan and streptozotocin action in $\beta$ cells of the rat pancreas. Physiol Res 2001; 50:536-546.

33. Saldeen J. Cytokines induce both necrosis and apoptosis via a common Bcl-2-inhibitable pathway in rat insulin-producing cells. Endocrinology 2000; 141:2003-2010.

34. Federici M, Hribal M, Perego L, Ranalli M, Caradonna Z, Perego C, Usellini L, Nano R, Bonini P, Bertuzzi F, Marlier LN, Davalli AM, Carandente O, Pontiroli AE, Melino G, Marchetti P, Lauro R, Sesti G, Folli F. High glucose causes apoptosis in cultured human pancreatic islets of Langerhans: a potential role for regulation of specific $\mathrm{Bcl}$ family genes toward an apoptotic cell death program. Diabetes 2001; 50:1290-1301.

35. Maedler K, Sergeev P, Ris F, Oberholzer J, JollerJemelka HI, Spinas GA, Kaiser N, Halban PA, Donath MY. Glucose-induced beta cell production of IL-1 beta contributes to glucotoxicity in human pancreatic islets. J Clin Invest 2002; 110:851-886.

36. Mellado-Gil JM, Aguilar-Diosdado M. High glucose potentiates cytokine- and streptozotocin-induced apoptosis of rat islet cells: effect on apoptosis-related genes. J Endocrinology 2004; 183:155-162. 


\section{PROTOCOLS}

\section{Rat islet isolation}

1. Kill animal by an appropriate method.

2. Open the abdominal cavity.

3. Close choledoco exit to the intestine by clamping.

4. Introduce a catheter into the part of the choledoco running from the liver to the pancreas.

5. Connect the catheter to a syringe and inject $15-20 \mathrm{ml}$ of a cold solution of colagenase $\mathrm{P}(1 \mathrm{mg} / \mathrm{ml})$ in HBSS until the pancreas is full.

6. Extract the filled pancreas by cutting out around the edges.

7. Incubate for $17-20 \mathrm{~min}$ at $37^{\circ} \mathrm{C}$ in agitation.

8. Homogenize the preparation with a pasteur pipette and add $60 \mathrm{ml}$ of HBSS+ BSA $(1 \mathrm{mg} / \mathrm{ml})$.

9. After 5-8 min placed in ice without movement, aspirate $15-20 \mathrm{ml}$ from the surface to eliminate fat and other floating debris.

10. Pass through a strainer to eliminate non digested tissue and then into a $50 \mathrm{ml}$ tube.

11. Centrifuge for $5 \mathrm{~min}$, at $1000 \mathrm{rpm}, 4^{\circ} \mathrm{C}$ and reject the supernatant.

12. Add to the "pellet" $10 \mathrm{ml}$. of Histopaque 1119 and resuspend. Put into $10 \mathrm{ml}$ of Histopaque $1077 \mathrm{and} 10 \mathrm{ml}$ of HBSS+ BSA to form a density gradient.

13. Centrifuge for $20-25 \mathrm{~min}$, at $2000 \mathrm{rpm}, 4^{\circ} \mathrm{C}$.

14. Take the interphase between Histopaque 1077 and HBSS+ BSA $(10-15 \mathrm{ml})$ and put it in a $50 \mathrm{ml}$ tube.

15. Fill to 50 and wash by centrifuging for $5 \mathrm{~min}$, at $100 \mathrm{rpm}, 4^{\circ} \mathrm{C}$.

16. Aspirate $30 \mathrm{ml}$ of supernatant, homogenize the islet suspension gently with a pipette and put onto a black Petri plate.

17. Using the stereo microscope and micropipette, collect 100-150 islets on each $60 \mathrm{~cm}$ culture plate with $5 \mathrm{ml}$ of culture medium).

\section{Sensitization protocol}

Sensitization to STZ-induced damage:

1. Culture islets for a sensitization period of $48 \mathrm{~h}$ with RPMI-completed medium supplemented with 5.5 or $24.4 \mathrm{mM}$ glucose.

2. Replace medium with fresh culture medium supplemented with $5.5 \mathrm{mM}$ glucose for the all islets, maintaining separated the batches of islets according to the previous glucose concentration (during the sensitization period).

3. Add STZ to islet cultures.

4. Culture for $24 \mathrm{~h}$.

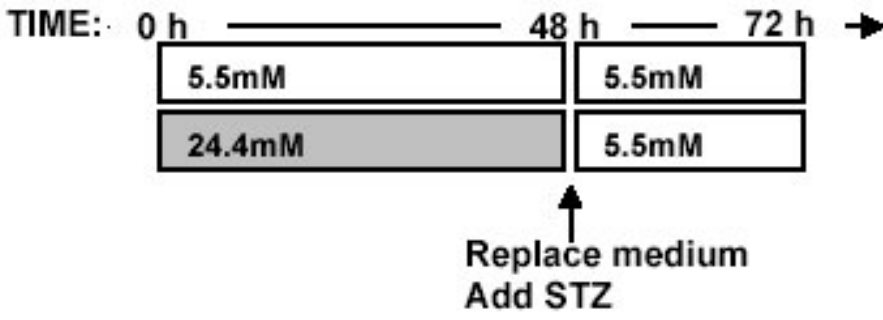


171

Sensitization to cytokine-induced damage:

1. Culture islets for an overnight period ( $\approx 14-16 \mathrm{~h})$ with RPMI-completed medium supplemented with 5.5 or $24.4 \mathrm{mM}$ glucose.

2. Replace with fresh medium maintaining both glucose concentrations.

3. Add IL- $1 \beta(50 \mathrm{U} / \mathrm{ml})$ alone or IL- $1 \beta+\mathrm{TNF}-\alpha(1000 \mathrm{U} / \mathrm{ml})+\mathrm{IFN}-\gamma(1000 \mathrm{U} / \mathrm{ml})$.

4. Culture for an incubation period of $24 \mathrm{~h}$.

TIME: $0 \mathrm{~h}$ $14-16 \mathrm{~h} \cdot 38-40 \mathrm{~h}$

\begin{tabular}{|l|l|}
\hline $5.5 \mathrm{mM}$ & $5.5 \mathrm{mM}$ \\
\hline \hline $24.4 \mathrm{mM}$ & $24.4 \mathrm{mM}$ \\
\hline
\end{tabular}

